\title{
INTEGRATED REGENERATION METHOD FOR USED MINERAL MOTOR OILS
}

\author{
Bohdan Korchak $^{1,}{ }^{\otimes}$, Oleg Grynyshyn ${ }^{1}$, Taras Chervinskyy $^{1}$, \\ Andriy Nagurskyy ${ }^{1}$, Vitalii Stadnik ${ }^{1}$
}

https://doi.org/10.23939/chcht15.02.239

\begin{abstract}
The scheme of the integrated regeneration method for used mineral motor oils (UMMO) has been developed, according to which M-10DM and NORMAL $15 \mathrm{~W} 40$ used oils were regenerated. A study on changes in physico-chemical properties, qualitative and elemental composition was carried out, and a mathematical model of the process was built. The further applications of the obtained products were proposed. Based on the obtained results, the technological scheme and flow chart of UMMO integrated regeneration were developed, and the process material balance was calculated.
\end{abstract}

Keywords: thermooxidative regeneration, used oil, IR spectroscopy, X-ray fluorescence analysis, purification with urea, vacuum distillation.

\section{Introduction}

The need for quality lubricants is growing throughout the world every year. In particular, according to the annual survey of the National Institute of Lubricants, oil production in Europe increased by $1.2 \%$ in 2018. The study also collected data on the use of base oils produced in Europe, according to which $86.5 \%$ were used as mineral base oils; $10.4 \%$ - as synthetic ones; $3.1 \%-$ as semi-synthetic oils [1].

At the same time, with the annual growth of marketable oils consumption in the world, the number of used oils accordingly increases, leading to their accumulation that negatively affects the environment and creates a problem of their reasonable utilization. The main "producers" of used oils (UO) in Ukraine are industry $(28 \%)$, transport $(38 \%)$, agriculture $(23 \%)$ and construction $(11 \%)$ [2]. Today, the recycling is foremost a concern for the environment and future generations!

There are various methods and technologies of regeneration and utilization of used oils, which allow to

\footnotetext{
${ }^{1}$ Lviv Polytechnic National University,

12, Bandery St., 79013 Lviv, Ukraine

kor4ak93@gmail.com

(c) Korchak B., Grynyshyn O., Chervinskyy T., Nagurskyy A., Stadnik V., 2021
}

reuse them in various industries. They may be used to produce components of diesel fuel [3, 4], highly effective preservatives [5] or corrosion inhibitors [6]. UO can also be used as a bitumen modifier $[7,8,9,10,11]$ or as the reagent for coal sludge flotation.

The regeneration of UMMO obtained from gasoline and diesel combustion engines involves analysis of their aging products and changes in physico-chemical properties, as well as the requirements for regenerated oils to ensure the economic feasibility and obtaining high quality regenerated oil. According to the results represented in [12-14], UMMO were regenerated by three different methods.

Nevertheless, it can be stated that none of the studied methods makes it possible to obtain a regenerated oil, which would correspond to the base oil of the corresponding brand by all indices. Therefore, it is necessary to carry out an integrated regeneration of used oils with the right combination of previously studied methods.

In our opinion, it is possible to create a new complex process of UO regeneration on the basis of combined technologies [12-14], which will include the thermooxidative regeneration and the purification of regenerated oil with urea. The resulting regenerated oil, in terms of its operational properties, will correspond to the component of the base oil, which after the introduction of additives can be reused according to its destination.

Earlier we studied the change of operational properties and group hydrocarbon composition of M-10DM and NORMAL 15W40 used oils, confirmed the formation of oxygen-containing products of "aging" during oils long-term use in the combustion engines and determined the change in inorganic part of UO $[15,16]$. The obtained results can be used to select the optimal technology for used oils regeneration.

The purpose of this work was to develop the basics of UMMO regeneration technology, namely, substantiation and creation of the basic technological scheme, as well as development of technological recommendations for the regeneration process of M-10DM and NORMAL 15W40. 


\section{Experimental}

The initial materials for the studies were M-10DM and NORMAL 15W40 used oils, removed from the crankcases of diesel and gasoline engines, respectively, after the end of their service life.

The process of UMMO integrated regeneration took place according to the following scheme (Fig. 1).

According to the proposed scheme, the used mineral motor oil must first be directed for thermooxidative regeneration, followed by vacuum distillation. As a result of these two stages, the viscositytemperature properties are improved, as well as light components and the majority of asphalt-resins and polycyclic aromatic hydrocarbons are separated. Then, if necessary, the oil fraction is directed for regeneration with urea in order to reduce the acidity of the oil.

The following physico-chemical properties were determined: the density (by the pycnometric method), the refractive index (using a refractometer), the viscosity (by the viscometric method) and the flash point (open cup) [17]. The group hydrocarbon composition of the oils was studied by chromatographic method. ASK silica gel was used as the adsorbent. The hydrocarbon fractions were washed out with petroleum ether and benzene, and the asphalt-resins were desorbed with an alcohol-benzene mixture.

The elemental composition of oils was determined by X-ray fluorescence spectral analysis. A precision analyzer Elvax Light SDD was used, the purpose of which is to determine the mass fraction of chemical elements in homogeneous monolithic and powdery objects. For the analysis the oil samples were burned at a temperature of $723 \mathrm{~K}$ for $4 \mathrm{~h}$, cooled in a desiccator and ground into a powder [18].

Infrared spectroscopic studies were performed on a Spectrum Two FT-IR spectrometer from PerkinElmer in a $0.1036 \mathrm{~mm}$ zinc selenide cuvette. The program Spectrum v.10.03.06 was used.

Mathematical modelling of thermooxidative regeneration was performed using Mathcad 15.0 software [19].

Table 1

Characteristics of M-10DM and NORMAL $15 W 40$ used oils

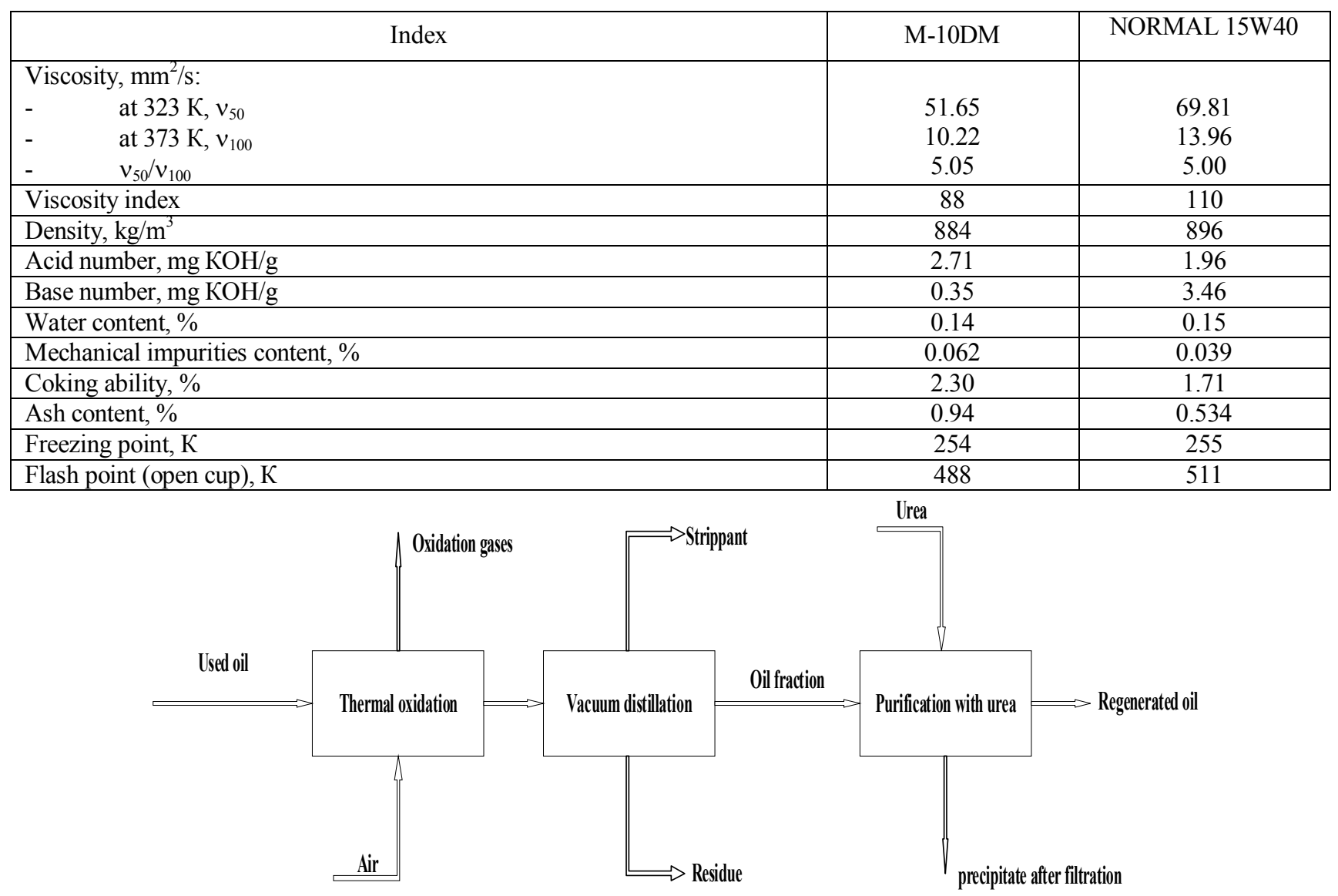

Fig. 1. The block- scheme of UMMO integrated regeneration 


\section{Results and Discussion}

\subsection{Integrated Method for UMMO Regeneration}

To confirm the reliability of the proposed integrated method, the regeneration of M-10DM and NORMAL 15W40 used oils was carried out in the previously determined optimal conditions:

- thermooxidative regeneration [13]: temperature $473 \mathrm{~K}$, pressure $2 \mathrm{MPa}$, time $2 \mathrm{~h}$;

- regeneration with urea [14]: temperature $413 \mathrm{~K}$, time $80 \mathrm{~min}$, the amount of urea is $5 \mathrm{wt} \%$ raw materials.
The results of UMMO regeneration by the integrated method under optimal conditions are given in Tables 2 and 3.

As a result of UMMO regeneration it was possible to obtain regenerated oils, the operational properties of which satisfy the requirements of those of commercial oils (Tables 2 and 3). Regenerated oils are characterized by good viscosity-temperature properties, low acid value, mechanical impurities, water and ash content. All indices of regenerated oils, except for the base number, meet the requirements for commercial oils of the respective brands. However, it is known that the base number is associated with the use of detergent-dispersing additives, which are introduced into the oil during its preparation.

Table 2

Characteristics of regenerated M-10DM oil

\begin{tabular}{|l|c|c|c|c|}
\hline \multirow{2}{*}{ Index } & \multicolumn{3}{c|}{ M-10DM } \\
\cline { 2 - 5 } & Strippant & Regenerated oil & Residue & Requirements for oil [20] \\
\hline Viscosity, $\mathrm{mm}^{2} / \mathrm{s}:$ & & & & \\
$-\quad \quad$ at $323 \mathrm{~K}, v_{50}$ & 37.85 & 63.19 & 117.18 & - \\
$-\quad$ at $373 \mathrm{~K}, v_{100}$ & 8.96 & 12.52 & 16.66 & - \\
$-\quad v_{50} / v_{100}$ & 4.22 & 5.04 & 7.03 & $\geq 90$ \\
\hline Viscosity index & 115 & 101 & 74 & $\leq 905$ \\
\hline Density, $\mathrm{kg} / \mathrm{m}^{3}$ & 862 & 865 & 910 & - \\
\hline Acid number, mg KOH/g & 1.54 & 0.20 & 2.05 & $\geq 8.2$ \\
\hline Base number, mg KOH/g & 2.87 & 0.15 & 0.12 & traces \\
\hline Water content, \% & - & traces & - & $\leq 0.025$ \\
\hline Mechanical impurities content, \% & traces & 0.005 & 0.198 & - \\
\hline Coking ability, \% & - & 1.15 & 6.84 & $\leq 1.5$ \\
\hline Ash content, \% & 0.003 & 0.018 & 4.21 & $\leq 255$ \\
\hline Freezing point, K & 252 & 250 & 259 & $\geq 493$ \\
\hline Flash point (open cup), K & 478 & 508 & 543 & - \\
\hline Fraction yield, wt \% & 7.05 & 71.4 & 13.36 & \\
\hline
\end{tabular}

Table 3

Characteristics of regenerated NORMAL 15W40 oil

\begin{tabular}{|c|c|c|c|c|}
\hline \multirow{2}{*}{ Index } & \multicolumn{4}{|c|}{ NORMAL 15W40 } \\
\hline & Strippant & Regenerated oil & Residue & Requirements for oil [21] \\
\hline Viscosity, $\mathrm{mm}^{2} / \mathrm{s}:$ & & & & \\
\hline at $323 \mathrm{~K}, v_{50}$ & 37.85 & 81.29 & 81.30 & - \\
\hline at $373 \mathrm{~K}, v_{100}$ & 8.96 & 15.89 & 13.56 & $12.5-16.3$ \\
\hline$v_{50} / v_{100}$ & 4.22 & 5.11 & 5.99 & \\
\hline Viscosity index & 115 & 120 & 75 & $\geq 120$ \\
\hline Density, $\mathrm{kg} / \mathrm{m}^{3}$ & 862 & 900 & 918 & $\leq 905$ \\
\hline Acid number, $\mathrm{mg} \mathrm{KOH} / \mathrm{g}$ & 1.45 & 0.15 & 1.49 & - \\
\hline Base number, mg KOH/g & 2.87 & 1.85 & 1.89 & $\geq 8.5$ \\
\hline Water content, \% & - & traces & - & traces \\
\hline Mechanical impurities content, \% & traces & 0.007 & 0.165 & $\leq 0.015$ \\
\hline Coking ability, \% & - & 1.12 & 6.73 & - \\
\hline Ash content, \% & 0.003 & 0.029 & 1.58 & $\leq 1.5$ \\
\hline Freezing point, $\mathrm{K}$ & 252 & 251 & 258 & $\leq 243$ \\
\hline Flash point (open cup), $\mathrm{K}$ & 478 & 523 & 533 & $\geq 478$ \\
\hline Fraction yield, wt $\%$ & 7.23 & 72.0 & 13.5 & - \\
\hline
\end{tabular}


To study the dependence of the viscosity ratio $v_{50} / v_{100}$, viscosity index, density, acid number, base number and flash point of regenerated oil on the temperature, pressure and duration of regeneration, a mathematical model of the third degree was created:

$$
\begin{aligned}
& y=\sum_{1 \leq i \leq q}^{q} b_{i} \cdot x_{i}+\sum_{1 \leq i \leq j \leq q}^{q} b_{i j} \cdot x_{i} \cdot x_{j}+ \\
& +\sum_{1 \leq i \leq j \leq q}^{q} \gamma_{i j} \cdot x_{i} \cdot x_{j} \cdot\left(x_{i}-x_{j}\right)+ \\
& +\sum_{1 \leq i \leq j \leq k \leq q}^{q} b_{i j k} \cdot x_{i} \cdot x_{j} \cdot x_{k} ;
\end{aligned}
$$

where $b$ and $\gamma$ are regression coefficients.

In this case, the number of parameters of the model is three, so the following regression equations are possible:

$$
\begin{gathered}
y_{1}=b_{1} x_{1}+b_{2} x_{2}+b_{3} x_{3}+b_{12} x_{1} x_{2}+b_{13} x_{1} x_{3}- \\
-b_{23} x_{2} x_{3}++\gamma_{12} x_{1} x_{2}\left(x_{1}-x_{2}\right)+\gamma_{13} x_{1} x_{3}\left(x_{1}-x_{3}\right)+ \\
+\gamma_{23} x_{2} x_{3}\left(x_{2}-x_{3}\right)-b_{123} x_{1} x_{2} x_{3} \\
y_{2}=b_{1} x_{1}+b_{2} x_{2}-b_{3} x_{3}-b_{12} x_{1} x_{2}-b_{13} x_{1} x_{3}- \\
-b_{23} x_{2} x_{3}+\gamma_{12} x_{1} x_{2}\left(x_{1}-x_{2}\right)-\gamma_{13} x_{1} x_{3}\left(x_{1}-x_{3}\right)- \\
-\gamma_{23} x_{2} x_{3}\left(x_{2}-x_{3}\right)+b_{123} x_{1} x_{2} x_{3} \\
y_{3}=-b_{1} x_{1}+b_{2} x_{2}-b_{3} x_{3}-b_{12} x_{1} x_{2}+b_{13} x_{1} x_{3}- \\
-b_{23} x_{2} x_{3}+\gamma_{12} x_{1} x_{2}\left(x_{1}-x_{2}\right)-\gamma_{13} x_{1} x_{3}\left(x_{1}-x_{3}\right)- \\
-\gamma_{23} x_{2} x_{3}\left(x_{2}-x_{3}\right)+b_{123} x_{1} x_{2} x_{3} \\
y_{4}=b_{1} x_{1}+b_{2} x_{2}+b_{3} x_{3}+b_{12} x_{1} x_{2}+b_{13} x_{1} x_{3}- \\
-b_{23} x_{2} x_{3}+\gamma_{12} x_{1} x_{2}\left(x_{1}-x_{2}\right)+\gamma_{13} x_{1} x_{3}\left(x_{1}-x_{3}\right)+ \\
+\gamma_{23} x_{2} x_{3}\left(x_{2}-x_{3}\right)-b_{123} x_{1} x_{2} x_{3} \\
y_{5}=b_{1} x_{1}+b_{2} x_{2}-b_{3} x_{3}-b_{12} x_{1} x_{2}-b_{13} x_{1} x_{3}- \\
-b_{23} x_{2} x_{3}+\gamma_{12} x_{1} x_{2}\left(x_{1}-x_{2}\right)-\gamma_{13} x_{1} x_{3}\left(x_{1}-x_{3}\right)- \\
-\gamma_{23} x_{2} x_{3}\left(x_{2}-x_{3}\right)+b_{123} x_{1} x_{2} x_{3} \\
y_{6}=-b_{1} x_{1}+b_{2} x_{2}-b_{3} x_{3}-b_{12} x_{1} x_{2}-b_{13} x_{1} x_{3}- \\
-b_{23} x_{2} x_{3}+\gamma_{12} x_{1} x_{2}\left(x_{1}-x_{2}\right)-\gamma_{13} x_{1} x_{3}\left(x_{1}-x_{3}\right)- \\
-\gamma_{23} x_{2} x_{3}\left(x_{2}-x_{3}\right)+b_{123} x_{1} x_{2} x_{3}
\end{gathered}
$$

where the parameters of the mathematical model are: $x_{1}-$ the regeneration temperature, $\mathrm{K} ; x_{2}$ - the regeneration time, $\mathrm{h} ; x_{3}$ - regeneration pressure, $\mathrm{MPa}$; response functions are: $y_{1}$ - the viscosity ratio $v_{50} / v_{100} ; y_{2}$ - the viscosity index; $y_{3}-$ density, $\mathrm{kg} / \mathrm{m}^{3} ; y_{4}$ - the acid number, $\mathrm{mg} \mathrm{KOH} / \mathrm{g} ; y_{5}$ - the base number, $\mathrm{mg} \mathrm{KOH} / \mathrm{g} ; y_{6}-$ flash point, $\mathrm{K}$.

Substituting into the equation for $y_{1}$ all values of parameters $x_{1}, x_{2}$ and $x_{3}$ and the values of $y_{1}$ corresponding to each set of parameters, we obtain a system of equations, the solution of which gives the values of the regression coefficients for this response function (Table 4). Similarly, we obtain systems of equations for other response functions of the mathematical model $\left(y_{2}, y_{3}, y_{4}, y_{5}, y_{6}\right)$. After solving each system of equations, we obtain a set of regression coefficients for each response function. The computer program Mathcad 15.0 was used to solve the system of equations.

We check the adequacy of the obtained mathematical model, substituting the values of the parameters and comparing the values of the response functions calculated in this way with the experimental data.

Substituting the obtained values of the regression coefficients into the regression equation and marking the parameters of the model and the response function with symbols that reflect their physical meaning, we obtain the final form of the mathematical model:

- for viscosity ratio $v_{50} / v_{100}$ : $y_{1}=0.00925 x_{1}+0.411 x_{2}+0.007699 x_{3}+$ $0.001597 x_{1} x_{2}+0.000350 x_{1} x_{3}-0.129 x_{2} x_{3}+$

$0.00000036 x_{1} x_{2}\left(x_{1}-x_{2}\right)+0.00000638 x_{1} x_{3}\left(x_{1}-x_{3}\right)+$ $0.0000242 x_{2} x_{3}\left(x_{2}-x_{3}\right)-0.000657 x_{1} x_{2} x_{3}$

- for viscosity index:

$y_{2}=0.00322 x_{1}+2.355 x_{2}-0.0022 x_{3}-0.0064 x_{1} x_{2}-$ $0.0476 x_{1} x_{3}-0.0445 x_{2} x_{3}+0.000273 x_{1} x_{2}\left(x_{1}-x_{2}\right)-$ $0.000497 x_{1} x_{3}\left(x_{1}-x_{3}\right)-0.000399 x_{2} x_{3}\left(x_{2}-x_{3}\right)+$ $0.0161 x_{1} x_{2} x_{3}$

Table 4

Values of calculated regression coefficients

\begin{tabular}{|c|c|c|c|c|c|c|}
\hline & $v_{50} / v_{100}$ & Viscosity index & Density & Acid number & Base number & Flash point \\
\hline$b_{1}$ & 0.00925 & 0.00322 & -0.0000324 & 0.000689 & 0.000246 & -0.000558 \\
\hline$b_{2}$ & 0.411 & 2.355 & 0.09393 & 0.000252 & 0.000182 & 0.07521 \\
\hline$b_{3}$ & 0.007699 & -0.0022 & -0.00511 & 0.000094 & -0.000005 & -0.00423 \\
\hline$b_{12}$ & 0.001597 & -0.0064 & -0.00482 & 0.0000747 & -0.000044 & -0.00853 \\
\hline$b_{13}$ & 0.000350 & -0.0476 & 0.00750 & 0.0000543 & -0.000000292 & 0.000436 \\
\hline$b_{23}$ & -0.129 & -0.0445 & -0.00461 & -0.000297 & -0.000000277 & -0.000257 \\
\hline$\gamma_{12}$ & 0.00000036 & 0.000273 & 0.00726 & 0.00000005 & 0.000000023 & 0.00607 \\
\hline$\gamma_{13}$ & 0.00000638 & -0.000497 & -0.00361 & 0.00000004 & -0.000000994 & -0.000309 \\
\hline$\gamma_{23}$ & 0.0000242 & -0.000399 & -0.000073 & 0.00000195 & -0.00000955 & -0.00000317 \\
\hline$b_{123}$ & -0.000657 & 0.0161 & 0.000767 & -0.00000155 & 0.000000886 & 0.0000669 \\
\hline
\end{tabular}


- for density:

$$
\begin{gathered}
y_{3}=-0.0000324 x_{1}+0.09393 x_{2}- \\
-0.00511 x_{3}-0.00482 x_{1} x_{2}+0.00750 x_{1} x_{3}- \\
-0.00461 x_{2} x_{3}+0.00726 x_{1} x_{2}\left(x_{1}-x_{2}\right)- \\
-0.00361 x_{1} x_{3}\left(x_{1}-x_{3}\right)-0.000073 x_{2} x_{3}\left(x_{2}-x_{3}\right)+ \\
+0.000767 x_{1} x_{2} x_{3} \\
-\quad \text { for acid number: } \\
y_{4}=0.000689 x_{1}+0.000252 x_{2}+0.000094 x_{3}+ \\
+0.0000747 x_{1} x_{2}+0.0000543 x_{1} x_{3}-0.000297 x_{2} x_{3}+ \\
+0.00000005 x_{1} x_{2}\left(x_{1}-x_{2}\right)+ \\
+0.00000004 x_{1} x_{3}\left(x_{1}-x_{3}\right)+0.00000195 x_{2} x_{3}\left(x_{2}-x_{3}\right)- \\
-0.00000155 x_{1} x_{2} x_{3} \\
-\quad \text { for base number: } \\
y_{5}=0.000246 x_{1}+0.000182 x_{2}-0.000005 x_{3}- \\
-0.000044 x_{1} x_{2}-0.000000292 x_{1} x_{3}-0.000000277 x_{2} x_{3}+ \\
+0.000000023 x_{1} x_{2}\left(x_{1}-x_{2}\right)-0.000000994 x_{1} x_{3}\left(x_{1}-x_{3}\right)- \\
-0.00000955 x_{2} x_{3}\left(x_{2}-x_{3}\right)+0.000000886 x_{1} x_{2} x_{3} \\
-\quad \text { for flash point: } \\
y_{6}=-0.000558 x_{1}+0.07521 x_{2}-0.00423 x_{3}-0.00853 x_{1} x_{2}+ \\
+0.000436 x_{1} x_{3}-0.000257 x_{2} x_{3}+0.00607 x_{1} x_{2}\left(x_{1}-x_{2}\right)- \\
-0.000309 x_{1} x_{3}\left(x_{1}-x_{3}\right)-0.00000317 x_{2} x_{3}\left(x_{2}-x_{3}\right)+ \\
\quad+0.0000669 x_{1} x_{2} x_{3}
\end{gathered}
$$

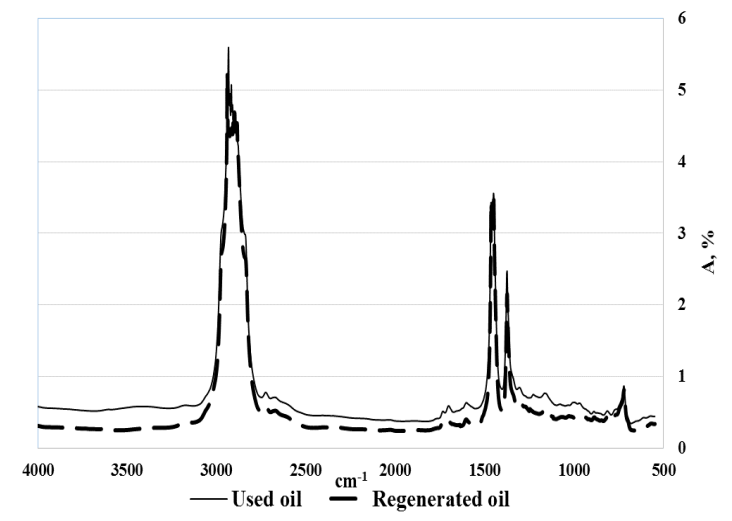

Fig. 2. IR spectra of used and regenerated M-10DM oil

IR spectra of NORMAL 15W40 used and regenerated oils, which are shown in Fig. 3, have a similar dependence. We can see a change in the absorption bands of oxygen-containing products of regenerated oil in contrast to the used one, which indicates a decrease in their content. The presence of oxygen-containing products in the IR spectra is confirmed by the change in the absorption bands of $\mathrm{C}=\mathrm{O}$ in the region of $1740-1690 \mathrm{~cm}^{-1}$, as well as by stretching vibrations at $1820-1740 \mathrm{~cm}^{-1}$ and asymmetric stretching vibrations of $\mathrm{C}-\mathrm{O}$ bond in the region of $1260-1150 \mathrm{~cm}^{-1}$.

\subsection{X-Ray Fluorescence Analysis}

The results of X-ray fluorescence analysis show the presence of individual elements in the used oils. These
The regression equations obtained as a result of mathematical modelling allow us to determine the dependence of the main indices on the regeneration temperature, pressure and time.

\subsection{IR Spectral Analysis}

To confirm the decrease in the content of oxygencontaining products in the regenerated oil, the IR spectroscopy was used. The analysis results are shown in Figs. 2 and 3.

As can be seen from Fig. 2, IR spectra of used and regenerated M-10DM oil differ by absorption bands of oil hydrocarbons. Paraffin-naphthenic hydrocarbons in the IR spectra of the studied oils were identified by stretching vibrations at $2935-2915 \mathrm{~cm}^{-1}$, as well as deformation vibrations of the $\mathrm{CH}$ group at $1470-1445 \mathrm{~cm}^{-1}$ and stretching vibrations of the $\mathrm{C}-\mathrm{C}$ group in the range of $1740-1720 \mathrm{~cm}^{-1}$. The presence of aromatic hydrocarbons in the oils was confirmed by the intense absorption band of the $\mathrm{CH}$ group at $860 \mathrm{~cm}^{-1}$. In addition, skeletal vibrations of the aromatic nucleus $\mathrm{C}-\mathrm{C}$ bond were detected by absorption bands in the region of 1610 $1600 \mathrm{~cm}^{-1}$ [22-24].

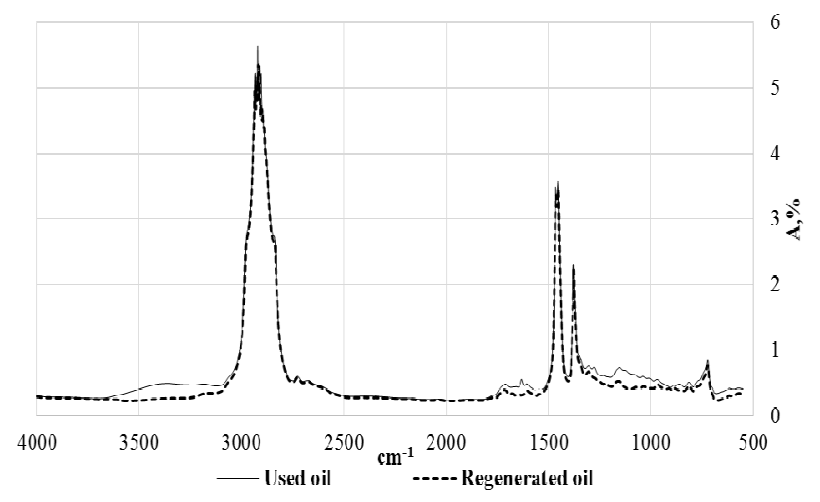

Fig. 3. IR spectra of used and regenerated NORMAL 15W40 oil

elements are part of the additives used during the production of oils and the wear products of engine. Data on the presence of metals in the oil allow us to assess the technical condition of the engine.

Such metals as $\mathrm{Fe}, \mathrm{Ti}, \mathrm{Mn}, \mathrm{Mo}$ and $\mathrm{Pb}$ are mandatory components of any engine. During its operation, the microscopic metal particles are erased from the work surfaces and get into the engine oil. For example, iron is the main structural material contained in the most important parts of the engine: the cylinder block, crankshaft, camshaft, etc. Increased iron content in the used oil usually indicates wear of one or more engine components. Titanium is the main component of turbines, springs, and valves. Molybdenum, as a wear-resistant metal, is the most common in piston rings and bearings. 
Manganese and Strontium are found as the alloying additives with iron in some steels and may be part of shafts, valves, gears, and rolling bearings. Lead is often used to alloying alloys used in crankshaft bearings and liners. Its high content in UO indicates bearing wear. Calcium in oils is present in detergent-dispersing additives or corrosion inhibitors. Phosphorus and sulfur in small quantities are components of metal parts; they make the surface chemically inert. An increase in their content in UO indicates the wear of metal friction surfaces.

Another reason for the increase in the inorganic components number is the oil topping between oil change. This operation is periodically performed on engines with significant mileage to compensate for oil loss from burnout and leaks. In this case, only the organic part of the oil burns out, and inorganic components accumulate in the oil, which circulates in the lubrication system of the internal combustion engine.

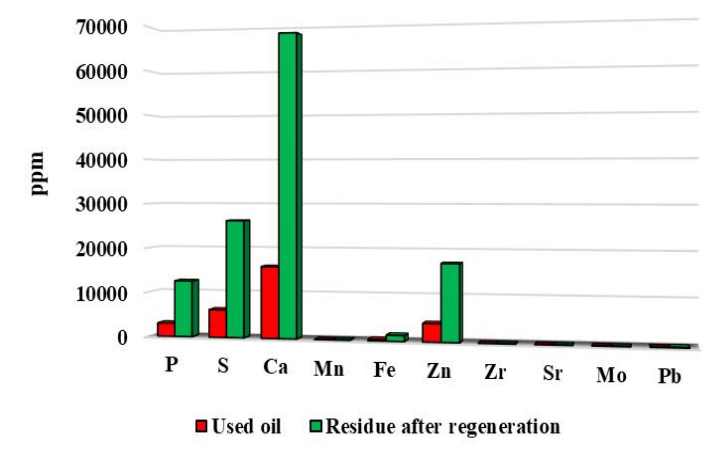

Fig. 4. The content of individual elements in the used oil M-10DM and in the residue after UMMO integrated regeneration, $\mathrm{ppm}$

The by-products which are produced in the process are:

- strippant (light fraction of vacuum distillation, initial boiling point- $653 \mathrm{~K}$ ) is characterized by relatively low viscosity and low ash value; it contains no water and mechanical impurities. This allows it to use the byproduct as a quantitative additive for diesel or fuel oil production;

- vacuum distillation residue is a mixture of highboiling oil hydrocarbons and asphalt-resins. It is characterized by high values of viscosity, density, coking ability and content of mechanical impurities. The main part of the inorganic components contained in UMMO is transferred to the residue. The residue of vacuum distillation can serve as a component of raw materials for the production of bitumen.

- precipitate after filtration is a mixture of urea and a small amount of oil components, acidic compounds,
The strippant and the main oil fraction obtained as a result of a complex regeneration process were characterized by low ash content and coking ability (Tables 2 and 3). At the same time, the residues of the process had much higher values of these indices. Therefore, an important stage of the work was to establish the inorganic composition of residues obtained as a result of UMMO integrated regeneration (Figs. 4 and 5).

Therefore, based on the obtained results, we can assert that the developed integrated method of UMMO regeneration allows to obtain regenerated oils, which will serve as a component for the production of commercial oils. This method does not require the use of expensive reagents and is characterized by high yield of the resulting product - regenerated oil and low yield of by-products. The advantage of the integrated method of UMMO regeneration is the relative simplicity in the hardware design, which allows the process implementation both at mini-plants and at large refineries.

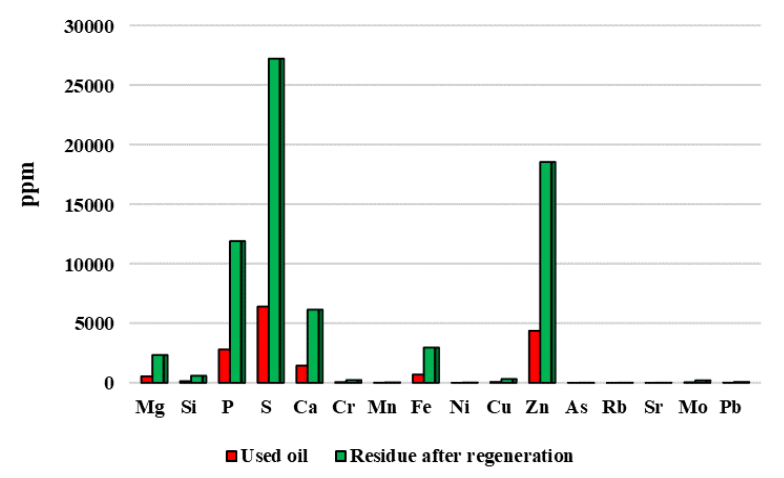

Fig. 5. The content of individual elements in the used oil NORMAL 15W40 and in the residue after UMMO integrated regeneration, ppm

inorganic components of UO and mechanical impurities. It is advisable to direct this by-product for separation by physical methods, after which it can serve as a raw material for the bitumen production.

\subsection{Technological Aspects of the UMMO Integrated Regeneration}

Based on the above results, we developed a basic technological scheme, which is shown in Fig. 6.

The initial UMMO from the vessel V1 is fed by a pump $\mathrm{P} 1$ to the thermal oxidation reactor $\mathrm{R} 1$, where it is heated to the process temperature due to the supply of heat carrier to the heating shell of the reactor. After reaching the required temperature the oxidant (air) is supplied to the reactor by a compressor $\mathrm{C} 1$. At the top of $\mathrm{R} 1$ a vaporgas mixture is obtained, which is cooled in a water cooler 
and then separated in the separator S1. The resulting gases are directed to the flare system for combustion.

The thermo-oxidized oil passes from the bottom of the reactor to the vessel V2, and then it is additionally heated in a tube furnace F1. The separation of the product takes place in the vacuum column $\mathrm{K} 1$. The top product is a strippant (light fraction), which condenses in the air cooler $\mathrm{AC} 1$ and enters storage. The bottom product is the vat residue, which is removed from the plant and can serve as a raw material for the production of bitumen.

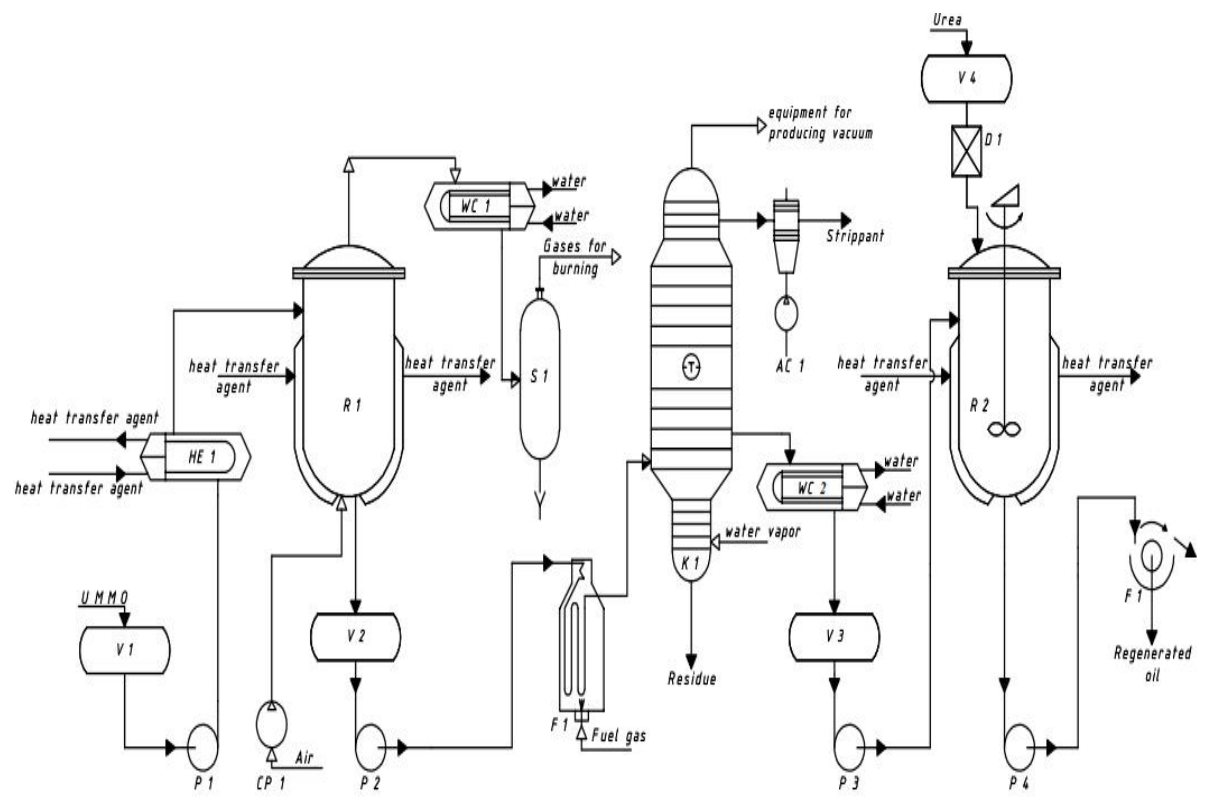

Fig. 6. The basic technological scheme of UMMO integrated regeneration: V1, V2, V3, V4 - vessels;

P1, P2, P3, P4 - pumps; HE1 - heat exchanger; R1 - thermal oxidation reactor; R2 -purification reactor with urea; K1 - vacuum column; AC1 - air cooler; WC1, WC2 - water coolers; S1 - separator; D1 - urea dispenser; F1 - tube furnace; F1 - filter

Table 5

Flow chart of the UMMO integrated regeneration process

\begin{tabular}{|l|c|c|}
\hline \multicolumn{1}{|c|}{ Parameter } & Units & Values \\
\hline Temperature in the reactor R1 & $\mathrm{K}$ & 473 \\
\hline Pressure in the reactor R1 & $\mathrm{MPa}$ & 2.0 \\
\hline Thermal oxidation time & $\mathrm{h}$ & 2.0 \\
\hline Temperature at the inlet to the column K1 & $\mathrm{kPa}$ & 638 \\
\hline Pressure in the column K1 & $\mathrm{K}$ & 5.6 \\
\hline Temperature in the reactor R2 & wt \% relative to oil & 413 \\
\hline Urea consumption & $\mathrm{h}$ & 5.0 \\
\hline Purification time & \multicolumn{2}{c|}{1.33} \\
\hline
\end{tabular}

Material balance of the UMMO integrated regeneration plant

\begin{tabular}{|l|c|c|c|}
\hline \multirow{2}{*}{ Raw materials/products } & \multicolumn{3}{c|}{ Amount } \\
\cline { 2 - 4 } & wt \% relative to raw material & tons/year & tons/cycle \\
\hline Entered & \multicolumn{3}{|c|}{} \\
\hline UMMO & 100.00 & 10000.00 & 22.22 \\
\hline Urea & 5.00 & 500.00 & 1.11 \\
\hline Total & 105.00 & 10500.00 & 23.33 \\
\hline Obtained & \multicolumn{3}{c|}{} \\
\hline Strippant & 7.23 & 723.00 & 1.61 \\
\hline Regenerated oil & 72.00 & 7200.00 & 16.00 \\
\hline Residue & 13.50 & 1350.00 & 3.00 \\
\hline Precipitate for separation & 7.27 & 727.00 & 1.62 \\
\hline Losses & 5.00 & 500.00 & 1.11 \\
\hline Total & 105.00 & 10500.00 & 23.33 \\
\hline
\end{tabular}


The oil fraction from $\mathrm{K} 1$ is cooled in a water cooler WC2, enters the vessel V3 and then fed by a pump P3 to the purification reactor with urea R2. Crystalline urea is fed to R2 from the vessel V4 through the dispenser D1. The oil fraction is fed from the bottom of the reactor R2 to the filter F1, in order to separate the unreacted urea. After filtration, the purified regenerated oil is fed into a container for storage.

The filtrate, which is a mixture of urea with oil components, is separated by physical methods; the separated urea is dried and fed back into the vessel V3. The advantage of this method is the obtaining of regenerated oil, which is characterized by the absence of asphalt-resins and low values of mechanical impurities and oxygen-containing aging products.

On the basis of experimental results the flow chart of the process (Table 5) was developed.

The UMMO regeneration plant can be used directly at refineries, which include vacuum distillation and bitumen production processes, as well as in the regions where used oils are centralized for their further regeneration. Taking these facts into account we accept the productivity of the UMMO regeneration plant as 10 thousands tons per year relative to the raw materials. The plant will operate for 225 days. Two regeneration cycles will be carried out during the day. The material balance of the UMMO regeneration unit is given in Table 6.

\section{Conclusions}

The principal possibility of application of the UMMO integrated regeneration method, which includes the process of thermooxidative regeneration, vacuum distillation and purification of regenerated oil with urea, has been established. Regeneration of M-10DM and NORMAL 15W40 used oils was carried out according to the developed scheme under previously established optimal conditions. It was established that regenerated oils can be used as base oils, and by-products of the process - strippant and residue - for the production of fuel or bitumen, respectively. The technological basics of the complex method of UMMO regeneration were developed, in particular the technological scheme and the flow chart of the process were proposed and the material balance was calculated.

\section{References}

[1] https://ecointel.com.ua/v-yevropi-zrostaye-vyrobnycztvo-mastyl/ [2] https://dzi.gov.ua/events/pererobka-vtorinnih-resursiv/

[3] Arpa O., Yumrutas R., Demirbas A.: Appl. Energ., 2010, 87, 122. https://doi.org/10.1016/j.apenergy.2009.05.042

[4] Maceiras R., Alfonsin V., Morales F.: Waste Manage., 2017, 60,

351. https://doi.org/10.1016/j.wasman.2016.08.009

[5] Pelitli V., Dogan O., Koroglu H.: Global J. Environ. Sci. Manage.,

2017, 3, 11. https://doi.org/10.22034/gjesm.2017.03.01.002
[6] Khalaf M., Tantawy A., Soliman K. et al.: J. Mol. Struct., 2020, 1203, 127442. https://doi.org/10.1016/j.molstruc.2019.127442

[7] Fernandes S., Silva H., Oliviera J.: Constr. Build. Mater., 2018, 160, 714. https://doi.org/10.1016/j.conbuildmat.2017.11.112

[8] Nagurskyy A., Khlibyshyn Y., Grynyshyn O.: Chem. Chem. Technol., 2017, 11, 226. https://doi.org/10.23939/chcht11.02.226 [9] Pyshyev S., Gunka V., Grytsenko Y. et al.: International Journal of Pavement Research and Technol., 2017, 10 (4), 289.

https://doi.org/10.1016/j.ijprt.2017.05.001

[10] Demchuk, Y., Gunka, V., Sidun, I., \& Solodkyy, S.: Proceedings of EcoComfort, 2020, 95. https://doi:10.1007/978-3-030-57340-9_12

[11] Gunka V., Demchuk Y., Sidun I. et al.: Petroleum \& Coal journal. ISSN 1337-7027. 2020, 62(2), 420/

[12] Korchak B., Hrynyshyn O., Chervinskyy T., Polyuzhin I.: Chem Chem. Technol., 2018, 12, 365. https://doi.org/10.23939/chcht12.03.365

「13] Korchak B., Grynyshyn O., Chervinskyy T. et al.: Chem. Chem. Technol., 2020, 14, 129. https://doi.org/10.23939/chcht14.01.129 「14] Korchak B., Hrynyshyn O., Chervinskyy T. et al.: Sci. Bull. UNFU, 2020, 30, 127. https://doi.org/10.36930/40300122

[15] Hrynyshyn O., Korchak B., Chervinskyy T., Kochubei V.: Chem. Chem. Technol., 2017, 11, 387. https://doi.org/10.23939/chcht11.03.387 [16] Korchak B., Hrynyshyn O., Chervinskyy T.: Sci. Bull. UNFU, 2017, 27, 93. https://doi.org/10.15421/402706

[17] Isaguliants V., Egorova G.: Khimiya Nefti. Khimia, Moskva 1965.

[18] https:/www.environmental-expert.com/products/elvax-modellight-sdd-light-spectrometer-566889

[19] Pinchuk S.: Organizatsia Experimentu pry Modeliuvanni ta Optymizatsii Technichnykh System. Dnipro VAL, Dnipropetrovsk 2009.

[20] http://agrinol.ua/en/catalog/masla/oils-for-automotive-diesels/m$10 \mathrm{dm} /$

[21] http://agrinol.ua/en/catalog/masla/universal-motor-oils/sae-15w-40sg-cd/

[22] Garry M., Bowman J.: FT-IR Analysis of Used Lubricating Oils General Considerations. Thermo Fisher Scientific 2007.

https:/assets.thermofisher.com/TFS-Assets/CAD/ApplicationNotes/D10256 .pdf

[23] Mironov V., Iankovskyy S.: Spectroscopia v Organicheskoi Khimii. Khimia, Moskva 1985.

[24] Tarasevych B.: IK Spectry Osnovnykh Klassov Organicheskykh Soedinenii. Khimia, Moskva 2021.

Received: October 06, 2019 / Revised: November 02, 2019 / Accepted: January 22, 2020

\section{КОМПЛЕКСНИЙ МЕТОД РЕГЕНЕРАЦӤ ВІДПРАЦЬОВАНИХ МІНЕРАЛЬНИХ МОТОРНИХ ОЛИВ}

Анотація. Розроблено поточну схему комплексного методу регенерачії відпрачьованих мінеральних моторних олив (ВММО), який включає проиес термоокиснювальної регенерачїі, вакуумну перегонку та доочищення регенерованої оливи карбамідом. Встановлено, щзо регенеровані оливи можуть використовуватись, як базові оливи, а побічні продукти проиесу - відгін та залишок - можуть використовуватись для виробництва палива та бітуму, відповідно. Розроблено основи технології комплексного методу регенераиії ВММО, зокрема запропоновано технологічну схему та технологічну карту процесу і проведено розрахунок матеріального балансу.

Ключові слова: термоокиснювальна регенерація, відпрацьована олива, ІЧ-спектроскопія, рентгенофлуоресцентний аналіз, очищення карбамідом, вакуумна перегонка. 